\title{
Saturated salt accelerated aging and computerized analysis of seedling images to evaluate soybean seed performance ${ }^{1}$
}

\author{
Juliana Tieme Yagushi ${ }^{*}$, Denis Santiago Costa ${ }^{3}$, José de Barros França-Neto ${ }^{4}$
}

\begin{abstract}
Seed deterioration causes losses to seed companies during the storage. For researches, the challenge has been to develop techniques which improve the seed longevity as well as laboratory analysis methods required for evaluating the evolution of deterioration in storage. This study had the objective of determining the effectiveness of the accelerated aging test with a saturated $\mathrm{NaCl}$ solution and Seed Vigor Imaging System (SVIS) analysis in checking soybean seed physiological in comparison with the recommended vigor tests. Soybean seeds from the cultivars BRS 184 and M-Soy 7908 RR were used, each of them were represented by six lots and stored for six months under two environment conditions. Seed physiological quality was checked every two months in storage through germination evaluations, accelerated aging (different methods), tetrazolium test (vigor and viability) seedling emergence, and SVIS analysis. The tetrazolium test is the most advisable method for evaluating soybean seed quality during storage. The results of the saturated salt accelerated aging test with $\mathrm{NaCl}$ at $41{ }^{\circ} \mathrm{C}$ for 72 or 96 hours and the SVIS evaluation are also both efficient for estimating the physiological potential of seeds.
\end{abstract}

Index terms: physiological potential, storage, Glycine max, SVIS.

\section{Envelhecimento acelerado e análise computadorizada de imagem de plântulas para avaliação do desempenho de sementes de soja}

\begin{abstract}
RESUMO - Deterioração em sementes provoca prejuízos para empresas sementeiras durante o armazenamento. Para os pesquisadores, o desafio tem sido buscar técnicas que visam aumentar a longevidade das sementes bem como métodos de análise laboratoriais exigidos para avaliar a evolução da deterioração no armazenamento. Este estudo teve o objetivo de avaliar a eficácia do teste de envelhecimento acelerado com solução saturada de $\mathrm{NaCl}$ e do uso do software Seed Vigor Imaging System (SVIS) para comparação do potencial fisiológico das sementes durante o armazenamento, em comparação com os testes de vigor existentes. Foram utilizadas sementes de soja das cultivares BRS 184 e M-Soy 7908 RR, representadas por seis lotes e armazenadas por seis meses, sob duas condições ambientais. Verificou-se o potencial fisiológico por meio de avaliações de germinação, envelhecimento acelerado (diferentes métodos), tetrazólio (vigor e viabilidade), emergência de plântulas e análise SVIS. O teste de tetrazólio é o mais sensível para avaliar o potencial fisiológico de sementes de soja durante o armazenamento. Além disso, os testes de envelhecimento acelerado em solução saturada de $\mathrm{NaCl}$ a $41{ }^{\circ} \mathrm{C}$ durante 72 horas ou 96 horas e análise a partir do software SVIS foram eficazes para estimar o potencial fisiológico de sementes de soja.
\end{abstract}

Termos para indexação: potencial fisiológico, armazenamento, Glycine max, SVIS.

\section{Introduction}

Soybean [Glycine max (L.) Merrill] seed quality is under constant investigation to identify production problems and find the best method to evaluate seed quality (Costa et al., 2003; Costa et al., 2005). The tetrazolium test is a method often adopted by the soybean seed industry in Brazil to evaluate the

Submitted on 02/12/2013. Accepted for publication on 04/10/2014.

${ }^{2}$ Departamento de Economia Rural, Secretaria da Agricultura e do Abastecimento, SEAB, Caixa Postal 1559, 80035-050- Curitiba, PR, Brasil. ${ }^{3}$ Departamento de Produção Vegetal, USP- ESALQ, Caixa Postal 9, 13418-900 - Piracicaba, SP, Brasil. seed quality, mainly due to its rapidity, precision, and also to identify causes of the reduction of seed physiological potential as mechanical damage, weathering damage and stinkbug injury (Moreano et al., 2011). Also, accelerated aging (AA) is often used in quality control programs by seed companies in the world because relatively reliable information on the storage potential of processed seed lots and potential seedling

\footnotetext{
${ }^{4}$ Embrapa Soja, Caixa Postal 231, 86001-970 - Londrina, PR, Brasil. *Corresponding author < juyagushi@gmail.com>
} 
emergence in the field can be acquired within a few days (Santos et al., 2002).

These two tests are important to estimate the seed physiological potential and provide results which allow the seed ranking by vigor, mainly the AA which is recommended internationally and recognized by the ISTA (International Seed Test Association, 2004) to evaluate the soybean seeds. However, one important aspect of accelerated aging tests is given from the difference in water uptake of each seed within a sample seed, which may result in high variation range in moisture content when exposed to a humid atmosphere. Alternative techniques have been studied to solve this problem, such as replacing water with saturated salt solutions. With this procedure relative air humidity of approximately $87 \%, 76 \%$ and $55 \%$, when $\mathrm{KCl}$, $\mathrm{NaCl}$ and $\mathrm{NaBr}$ are used, may be obtained thereby decreasing the rate of moisture content uptake, speed and intensity of seed deterioration (Jianhua and McDonald, 1996) with any reduction in test sensitivity. The efficiency of this procedure has been checked not only for small seeds (Ramos et al., 2004; Torres, 2005; Fessel et al., 2005; Barbosa et al., 2012) but also for larger ones (Marcos-Filho et al., 2009; Wrasse et al., 2009; Mendonça et al., 2008).

In addition to the accelerated aging and tetrazolium test, new techniques have been introduced by seed researchers to obtain relevant information about the physiological potential of the seeds. One recent approach is the computerized analysis of seedling images, which is one of the trends in seed technology (Matthews et al., 2012).

The Seed Vigor Imaging System (SVIS) was developed by the Ohio State University. It was firstly used to evaluate lettuce seedling images and was later adapted by Hoffmaster et al. (2003) for the evaluation of soybean seedlings. More recently this computer methodology has been improved for the validation of image analysis software and its potential of application for briefly testing for a large number of seed species. The technique needs yet to be developed in an acceptable way to allow the application of image analysis in seed laboratories on a daily basis (Matthews et al., 2012).

In this context, this study had the objective of determining the effectiveness of the accelerated aging test with a saturated $\mathrm{NaCl}$ solution and Seed Vigor Imaging System (SVIS) analysis in checking soybean seed physiological during the storage in comparison with the recommended vigor tests.

\section{Materials and Methods}

Soybean seeds from the cultivars BRS 184 and M-Soy 7908 RR were used; each cultivar was represented by six seed lots having germination percentage over the minimum standard (80\%) required for trade purpose.

The seeds from each seed lot were placed in cotton bags and stored in two environments; the controlled environment, at $20{ }^{\circ} \mathrm{C}$ and $76 \%$ relative air humidity $\left(\mathrm{A}_{1}\right)$ and a natural, uncontrolled environment, with a daily recorded temperature and relative air humidity $\left(\mathrm{A}_{2}\right)$. The aim was keep the seeds in this two environment because $A_{1}$ promoted relative humidity similar at the saturated salt accelerated aging with $\mathrm{NaCl}$ test and $A_{2}$ is similar that one used in warehouses. The seeds lots were stored for a six-month period and the seeds were checked every two months for germination and vigor tests.

Before starting each evaluation, the seed moisture contents were standardized, since seeds were stored under different environments due to variations of both temperature and relative humidity, which could affect the test results. Thus, for each storage period, both seeds stored in a controlled environment $\left(A_{1}\right)$ and seeds stored in an uncontrolled natural environment $\left(\mathrm{A}_{2}\right)$ were kept in a dry chamber $\left(20^{\circ} \mathrm{C}\right.$ and $50 \%$ relative air humidity) for approximately 7 days before testing, monitoring of temperature and relative humidity under both environment conditions throughout the storage period was made by thermohygro-graph device. The samples collected at the beginning and after two, four and six months of storage were evaluated by the following tests:

Seed moisture content: This parameter was determined by the oven method at $105^{\circ} \mathrm{C}$ for 24 hours (Brasil, 2009) in two replicates of seeds $(4.5 \pm 0.5 \mathrm{~g})$. The results were expressed as the average percentage (wet basis) per seed lot.

Germination: The test was performed with four replicates of 50 seeds each for each lot and cultivar in moistened paper rolls with an amount of water equivalent to 2.5 times the dry substrate weight and kept at $25{ }^{\circ} \mathrm{C}$ for seven days. The evaluation was conducted according to the Rules for Seed Testing (Brasil, 2009), and the results were expressed as percentage of normal seedlings for each lot.

First germination count: The number of normal seedlings determined at 4 days of the germination test was recorded according to the previously cited method.

Traditional accelerated aging: The seed samples were set on a single layer of aluminum screen and placed in plastic boxes $(11 \mathrm{~cm} \times 11 \mathrm{~cm} \times 3 \mathrm{~cm})$ containing $40 \mathrm{~mL}$ of water in the bottom, preventing the seeds from touching the water. The test was performed at $41^{\circ} \mathrm{C}$ for 48 hours (Baalbaki et al., 2009), followed by a germination test at $25^{\circ} \mathrm{C}$ in paper rolls moistened with an amount of water equivalent to 2.5 times the weight of the dry substrate. On the fourth day, the percentages of normal seedlings for each seed lot and cultivar were recorded.

Tetrazolium test: Six subsamples of fifty seeds were used for each treatment, totalizing three hundred seeds. 
These seeds were initially placed in moistened paper towels for approximately sixteen hours in a germinator at $25^{\circ} \mathrm{C}$ in the dark. At the end of incubation, seeds were transferred to plastic cups with a $50 \mathrm{~mL}$ capacity containing a solution of 2, 3, 5-triphenyltetrazolium chloride $(0.075 \%)$, where they were kept for approximately 150 minutes in oven at $40{ }^{\circ} \mathrm{C}$ in the dark. After developed coloration, the seeds were washed in running water and kept under water in a refrigerator for a maximum of three hours until the evaluation time. The evaluations were performed according to the criteria described for different species by França-Neto et al. (1998).

Emergence of seedlings in sand substrate: Four replicates of 50 seeds for each seed lot and cultivar were distributed into boxes containing sand. The water availability in the substrate was adjusted to $60 \%$ of its water capacity. On the $14^{\text {th }}$ day after sowing, the total percentage of emerged seedlings which reached at least VC stage, unifoliolate leaves unrolled in addition to cotyledons (Fehr and Caviness, 1977), was registered. To calculate the speed emergence index, counting was performed on a daily basis according to the previously mentioned criteria; the index was calculated according to Maguire formula (1962).

Saturated salt accelerated aging: This test was performed as before, but with the water replaced by $40 \mathrm{~mL}$ of a saturated $\mathrm{NaCl}$ solution $(40 \mathrm{~g} / 100 \mathrm{~mL})$. This test was performed at $41^{\circ} \mathrm{C}$ for 48,72 and 96 hours. After these periods, the germination tests were performed, and the percentages of normal seedlings were recorded at 4 days after sowing.

Analysis of seedling images: To obtain seedlings for this evaluation, four replicates of 25 seeds per seed lot were set for germination at $25^{\circ} \mathrm{C}$ for three days (Hoffmaster et al., 2003). The seedlings from each replication were placed on a black pasteboard sheet $(30 \mathrm{~cm} \times 22 \mathrm{~cm})$ and scanned by HP Scanjet 241D scanner which is operated by the Photosmart software at a resolution of 100 dpi. Digital images were analyzed with the SVIS software in accordance with Hoffmaster et al. (2003). The parameters obtained by this program were: seedling length (SL, cm), the vigor index (VI) and seedling uniformity index (U). The experiment was conducted with a completely randomized design, and the analyses were performed for each period, cultivar and environment and, when significant, the averages were compared by the Scott-Knott test $(\mathrm{p} \leq 0.05)$. The results of the tests were expressed as percentages and changed into arc sine $\sqrt{ } \mathrm{x} / 100$ when they were not adequate for the statistical assumptions of the mathematical model. To determine the effectiveness of each test for a better seed physiological quality testing, a Pearson correlation was used between the seedling emergence at the end of each time of traditional accelerated aging and the vigor observed by the tetrazolium test, saturated salt accelerated aging using $\mathrm{NaCl}$ treatment for 48, 72 and 96 hours, the vigor index, uniformity, and seedling length.

\section{Results and Discussion}

In the controlled environment $\left(\mathrm{A}_{1}\right)$, the temperature was kept at $20{ }^{\circ} \mathrm{C}$ for the entire storage period, with maximum variations of $2{ }^{\circ} \mathrm{C}$. Additionally, the relative humidity remained invariant at approximately $76 \%$, as established. In the uncontrolled environment $\left(\mathrm{A}_{2}\right)$, the temperature varied between $14.2^{\circ} \mathrm{C}$ and $27.9^{\circ} \mathrm{C}$, and the relative humidity varied between $58.2 \%$ and $78.3 \%$ because of weather changes. The seed lots had moisture contents between $7.6 \%$ and $8.6 \%$ prior to storage, and after storage, the seeds reached hygroscopic equilibrium once the seed moisture content in $\mathrm{A}_{1}$ had values between $12.2 \%$ and $13.5 \%$; this variation took place because of the opening in the storage containers. The seed moisture content in $\mathrm{A}_{2}$ changed according to the changes in environment conditions, always remaining between $12.2 \%$ and $13.6 \%$.

Before storage, for the seed lots of cultivar BRS 184, no significant differences were observed among the germination test results (Table 1); in other words, it was not possible to rank the seed lots according to this data. However, vigor test results (first germination count, accelerated aging tests, tetrazolium tests, speed emergence index, and seedling emergence) may classify these seeds by their physiological potential; in general, the results of the seeds from lot 3 for cultivar BRS 184 were inferior in all tests, except seedling emergence in sand substrate. On the other hand, the seeds from lot 2 were classified as high vigor, although there were variations in the lot classifications according to the vigor test used.

After two-months (data not shown) and four-months of storage, the conditions of both storage environments were similar and the seed moisture contents were between $12.2 \%$ and $13.5 \%$ for the controlled environment $\left(A_{1}\right)$ and uncontrolled environment $\left(\mathrm{A}_{2}\right)$. For the seeds of cultivar BRS 184 (Table 2), the storage location of the seeds $\left(A_{1}\right.$ and $\left.A_{2}\right)$ influenced the result of the germination test. Whereas in $A_{1}$, the germination percentage of the seeds remained at values higher than those established for commercial standards, in environment $\mathrm{A}_{2}$, a significant germination decrease occurred, mainly for seed lots 3 and 1 . At the beginning of the study, the seeds from lots 3 and 1 had already been classified as low performance, as indicated by a tetrazolium test (Table 1). In $A_{1}$, the results of vigor tests identified lot 3 as low vigor, similarly to the initial seed lot characterization. However, the results of the traditional accelerated aging test and the first germination count were not efficient for identifying lot 
1 as inferior. This trend could be observed in the seedling emergence in both environments (Table 2). It is important to emphasize the accuracy of the tetrazolium test for evaluating vigor, as within the same environment $\left(A_{1}\right.$ and $\left.A_{2}\right)$, this test correctly classified lots 2, 5 and 6 as high vigor, with similar results for seedling emergence.

Table 1. Germination (G), first germination count (FGC), traditional accelerated aging (TAA), viability - tetrazolium (VIA), vigor - tetrazolium (VIG), seed emergence index (SEI) and percentage of seedling emergence (E) from six lots of soybean seeds of the cultivars BRS 184 and M-Soy 7908 RR before storage.

\begin{tabular}{|c|c|c|c|c|c|c|c|c|}
\hline Cultivar & Seed Lot & ….............. & FGC & $\begin{array}{l}\text { TAA } \\
. .(\%) \ldots . .\end{array}$ & $\begin{array}{c}\text { VIA } \\
\ldots \ldots \ldots \ldots . . .\end{array}$ & $\begin{array}{l}\text { VIG } \\
\ldots \ldots \ldots \ldots\end{array}$ & $\begin{array}{c}\text { SEI } \\
-\end{array}$ & $\begin{array}{c}E \\
(\%)\end{array}$ \\
\hline \multirow{6}{*}{ BRS 184} & 1 & $91^{\text {n.s. }}$ & $89 a^{*}$ & $84 a^{*}$ & $93 b^{*}$ & $88 b^{*}$ & $10.7 \mathrm{a}^{*}$ & $87 \mathrm{~b}^{*}$ \\
\hline & 2 & 94 & $93 \mathrm{a}$ & $85 \mathrm{a}$ & $96 \mathrm{a}$ & $90 \mathrm{a}$ & $11.0 \mathrm{a}$ & $91 \mathrm{a}$ \\
\hline & 3 & 81 & $78 \mathrm{~b}$ & $74 \mathrm{~b}$ & $83 \mathrm{c}$ & $80 \mathrm{c}$ & $9.4 \mathrm{~b}$ & $89 \mathrm{a}$ \\
\hline & 4 & 90 & $86 \mathrm{a}$ & $80 \mathrm{~b}$ & $90 \mathrm{a}$ & $86 \mathrm{~b}$ & $10.6 \mathrm{a}$ & $86 \mathrm{~b}$ \\
\hline & 5 & 90 & $86 \mathrm{a}$ & $78 \mathrm{~b}$ & $95 \mathrm{a}$ & $91 \mathrm{a}$ & $10.6 \mathrm{a}$ & $92 \mathrm{a}$ \\
\hline & 6 & 84 & $81 \mathrm{~b}$ & $84 \mathrm{a}$ & $95 \mathrm{a}$ & $86 \mathrm{~b}$ & $10.4 \mathrm{a}$ & $90 \mathrm{a}$ \\
\hline C.V. (\%) & & 6.8 & 5.6 & 8.6 & 3.4 & 4.7 & 3.4 & 2.8 \\
\hline \multirow{6}{*}{ M-Soy 7908 RR } & 7 & $97^{\text {n.s. }}$ & $94^{\text {n.s. }}$ & $94 a^{*}$ & $98^{\text {n.s. }}$ & $95^{\text {n.s. }}$ & $11.8 \mathrm{a}^{*}$ & $99^{\text {n.s. }}$ \\
\hline & 8 & 96 & 92 & $85 \mathrm{~b}$ & 98 & 95 & $11.4 \mathrm{~b}$ & 98 \\
\hline & 9 & 97 & 96 & $94 \mathrm{a}$ & 97 & 93 & $11.9 \mathrm{a}$ & 99 \\
\hline & 10 & 97 & 95 & $92 \mathrm{a}$ & 99 & 96 & $11.8 \mathrm{a}$ & 97 \\
\hline & 11 & 97 & 92 & $84 \mathrm{~b}$ & 98 & 95 & $11.0 \mathrm{~b}$ & 97 \\
\hline & 12 & 97 & 92 & $86 \mathrm{~b}$ & 97 & 92 & $11.4 \mathrm{~b}$ & 97 \\
\hline C.V. (\%) & & 2.5 & 3.4 & 5.6 & 4.7 & 3.7 & 3.9 & 2.9 \\
\hline
\end{tabular}

n.s. non-significant; ${ }^{*}$ significant at $5 \%$. Means followed by the same letter in the columns for given cultivars do not differ from each other according to the ScottKnott test at $5 \%$ probability.

For M-Soy 7908 RR, there were no significant differences in the germination test results (Table 1). However, the vigor tests results (first germination count, accelerated aging tests, tetrazolium tests, speed emergence index, and seedling emergence) showed that only the accelerated aging tests and the seedling emergence index classified the seeds according to physiological potential (Table 1), ranking lots 8,11 and 12 as the ones with lower vigor; seeds from lots 7, 9 and 10 were classified as high vigor.

For seeds from cultivar M-Soy $7908 \mathrm{RR}\left(\mathrm{A}_{1}\right)$, the seeds from lots 8,11 and 12 had significantly decreased germination after 4 months (Table 2). The results of the accelerated aging test and the seedling emergence index had already displayed this difference in seed quality (Table 1); seeds from lot 11 were classified as low vigor in $A_{1}$ (Table 2). The results of the vigor tests, which differed from what was observed in the characterization of the seed lots (Table 1), were efficient for classifying the seeds by physiological potential. By this result it is inferred that when seed deterioration was present, it was possible to check quality variation. It was thus observed that in both environments $A_{1}$ and $A_{2}$, the seeds from lots 7 and 9 showed a higher physiological potential, as indicated by the results from the standard tests, even though the emergence of seedlings in sand substrate results did not support that idea.

With the correlation results (Table 3 ) was possible to infer that for cultivar BRS 184 had higher values, possibly because of the lower physiological potential of the seed lots compared to M-Soy 7908 RR. It was clear that the vigor noted with the tetrazolium test was the result that correlated the most with the emergence of seedlings, with a value for both cultivars of 0.873 against 0.702 of the traditional accelerated aging.

Regarding the study of seed vigor, the accelerated aging and tetrazolium tests stand out among the others because they generally present a correlation with emergence of seedlings in field, as reported by França-Neto et al. (2003). Torres et al. (2004) showed that accelerated aging tests and field seedling emergence were significant with correlation coefficients between 0.50 and 0.83 for seedling emergence. In this study, the correlation data between accelerated aging tests and seedling emergence changed from 0.59 to 0.84 , and these data confirmed the results previously reported (Tables 1 and 2). In this study, the traditional accelerated aging test was proved to be efficient for identifying seed lots of low physiological potential, even in presence of high values of germination percentage, as occurred in seeds from cultivar M-Soy 7908 RR (Table 1).

The decreased number of normal seedlings observed after the traditional accelerated aging test is explained by seed exposure to high temperature and relative humidity conditions, which cause metabolic changes with respect to 
the rate of respiration and the inefficiency of free radicalscavenging enzymes (Tian et al., 2008). In addition, the seeds under artificial aging are subjected to anatomical modification in the hypodermic layer of the testa and to a collapse of the hypodermic cells, which is associated with a loss of germination capacity (Silva et al., 2008).

Table 2. Germination (G), first germination count (FGC), traditional accelerated aging (TAA), viability-tetrazolium (VIA), vigor-tetrazolium (VIG), speed emergence index (SEI) and percentage of seedling emergence in sand (E) of six lots of soybean seeds of the cultivars BRS 184 and M-Soy 7908 RR, stored for four months in a controlled environment $\left(A_{1}\right)$ and a uncontrolled environment $\left(A_{2}\right)$.

\begin{tabular}{|c|c|c|c|c|c|c|c|c|c|}
\hline Cultivar & Environment & Seed Lot & G & FGC & $\begin{array}{l}\text { TAA } \\
\ldots(\%) \ldots\end{array}$ & VIA & VIG & $\begin{array}{c}\text { SEI } \\
-\end{array}$ & $\begin{array}{c}E \\
(\%)\end{array}$ \\
\hline \multirow{14}{*}{ BRS 184} & \multirow{6}{*}{$\mathrm{A}_{1}$} & 1 & $86^{\text {n.s. }}$ & $83 \mathrm{a}^{*}$ & $51 \mathrm{a}^{*}$ & $83 b^{*}$ & $67 b^{*}$ & $7.32 \mathrm{c}^{*}$ & $82 b^{*}$ \\
\hline & & 2 & 91 & 89 a & $62 \mathrm{a}$ & $90 \mathrm{a}$ & $74 \mathrm{a}$ & $7.92 \mathrm{~b}$ & 93 a \\
\hline & & 3 & 81 & $75 \mathrm{~b}$ & $34 \mathrm{c}$ & $70 \mathrm{c}$ & $51 \mathrm{c}$ & $6.52 \mathrm{c}$ & $72 b$ \\
\hline & & 4 & 86 & $82 \mathrm{a}$ & $46 \mathrm{~b}$ & $87 \mathrm{a}$ & $75 \mathrm{a}$ & $8.20 \mathrm{~b}$ & $81 \mathrm{~b}$ \\
\hline & & 5 & 85 & $85 \mathrm{a}$ & $56 \mathrm{a}$ & $90 \mathrm{a}$ & $74 \mathrm{a}$ & $9.39 \mathrm{a}$ & $88 \mathrm{a}$ \\
\hline & & 6 & 87 & $84 \mathrm{a}$ & $43 \mathrm{~b}$ & $89 \mathrm{a}$ & $76 \mathrm{a}$ & $8.81 \mathrm{a}$ & $88 \mathrm{a}$ \\
\hline & \multicolumn{2}{|c|}{ CV (\%) } & 4.1 & 5.8 & 8.6 & 4.2 & 2.9 & 7.3 & 7.7 \\
\hline & \multirow{6}{*}{$\mathrm{A}_{2}$} & 1 & $62 b^{*}$ & $58 b^{*}$ & $6 d^{*}$ & $64 d^{*}$ & $47 c^{*}$ & $4.81 b^{*}$ & $57 b^{*}$ \\
\hline & & 2 & $79 \mathrm{a}$ & $75 \mathrm{a}$ & $45 \mathrm{a}$ & $82 \mathrm{~b}$ & $68 \mathrm{a}$ & $7.53 \mathrm{a}$ & $85 \mathrm{a}$ \\
\hline & & 3 & $65 \mathrm{~b}$ & $59 \mathrm{~b}$ & $12 \mathrm{~d}$ & $63 \mathrm{~d}$ & $44 \mathrm{~d}$ & $4.31 \mathrm{~b}$ & $52 \mathrm{~b}$ \\
\hline & & 4 & $82 \mathrm{a}$ & $75 \mathrm{a}$ & $23 \mathrm{c}$ & $71 \mathrm{c}$ & $48 \mathrm{c}$ & $7.99 \mathrm{a}$ & $85 \mathrm{a}$ \\
\hline & & 5 & $74 \mathrm{a}$ & $67 \mathrm{a}$ & $28 \mathrm{c}$ & $82 \mathrm{~b}$ & $63 \mathrm{~b}$ & $7.00 \mathrm{a}$ & $80 \mathrm{a}$ \\
\hline & & 6 & $77 \mathrm{a}$ & $74 \mathrm{a}$ & $36 \mathrm{~b}$ & $86 \mathrm{a}$ & $69 \mathrm{a}$ & $7.51 \mathrm{a}$ & $83 \mathrm{a}$ \\
\hline & \multicolumn{2}{|c|}{ CV (\%) } & 7.3 & 8.1 & 11.0 & 2.6 & 2.2 & 9.2 & 8.9 \\
\hline \multirow{14}{*}{ M-Soy 7908 RR } & \multirow{6}{*}{$\mathrm{A}_{1}$} & 7 & $98 a^{*}$ & $95 a^{*}$ & $63 a^{*}$ & $97 a^{*}$ & $89 a^{*}$ & $9.65 \mathrm{a}^{*}$ & $94 \mathrm{a}^{*}$ \\
\hline & & 8 & $93 \mathrm{a}$ & $82 \mathrm{~b}$ & $29 \mathrm{~b}$ & $92 \mathrm{~b}$ & $82 \mathrm{c}$ & $8.39 \mathrm{~b}$ & $88 \mathrm{a}$ \\
\hline & & 9 & 96 a & $87 \mathrm{~b}$ & $70 \mathrm{a}$ & 96 a & $85 \mathrm{a}$ & $9.98 \mathrm{a}$ & $96 \mathrm{a}$ \\
\hline & & 10 & 94 a & $86 \mathrm{~b}$ & $35 \mathrm{~b}$ & $93 \mathrm{~b}$ & $85 \mathrm{~b}$ & $9.50 \mathrm{a}$ & $92 \mathrm{a}$ \\
\hline & & 11 & $90 \mathrm{~b}$ & $78 \mathrm{c}$ & $32 \mathrm{~b}$ & $92 \mathrm{~b}$ & $80 \mathrm{c}$ & $7.67 \mathrm{c}$ & $81 \mathrm{~b}$ \\
\hline & & 12 & 94 a & $85 \mathrm{~b}$ & $22 \mathrm{~b}$ & $93 \mathrm{~b}$ & $83 \mathrm{c}$ & $8.63 \mathrm{~b}$ & $91 \mathrm{a}$ \\
\hline & \multicolumn{2}{|c|}{ CV $(\%)$} & 4.0 & 4.3 & 16.9 & 3.1 & 2.6 & 5.4 & 5.6 \\
\hline & \multirow{6}{*}{$\mathrm{A}_{2}$} & 7 & $95 a^{*}$ & $89 a^{*}$ & $34 a^{*}$ & $96 a^{*}$ & $87 a^{*}$ & $9.26 \mathrm{a}^{*}$ & $93 a^{*}$ \\
\hline & & 8 & $86 \mathrm{~b}$ & $68 \mathrm{~b}$ & $8 \mathrm{~b}$ & $88 \mathrm{c}$ & $72 \mathrm{c}$ & $6.59 \mathrm{~d}$ & $77 \mathrm{c}$ \\
\hline & & 9 & 93 a & $87 \mathrm{a}$ & $40 \mathrm{a}$ & $94 \mathrm{~b}$ & $86 \mathrm{a}$ & $9.40 \mathrm{a}$ & 96 a \\
\hline & & 10 & 94 a & 89 a & $18 \mathrm{~b}$ & $94 \mathrm{~b}$ & $82 \mathrm{~b}$ & $8.75 \mathrm{~b}$ & $92 \mathrm{a}$ \\
\hline & & 11 & $88 \mathrm{~b}$ & $80 \mathrm{~b}$ & $15 \mathrm{~b}$ & $84 \mathrm{~d}$ & $65 \mathrm{~d}$ & $7.41 \mathrm{c}$ & $86 \mathrm{~b}$ \\
\hline & & 12 & $90 \mathrm{~b}$ & $81 \mathrm{~b}$ & $16 \mathrm{~b}$ & $93 \mathrm{~b}$ & $82 \mathrm{~b}$ & $8.66 \mathrm{~b}$ & $95 \mathrm{a}$ \\
\hline & \multicolumn{2}{|c|}{ CV (\%) } & 3.7 & 5.6 & 21.9 & 1.9 & 2.3 & 4.8 & 6.3 \\
\hline
\end{tabular}

n.s. non-significant; ${ }^{*}$ significant at 5\%. Means followed by the same letter in the column for each cultivar do not differ from each other as indicated by the Scott-Knott test at $5 \%$ probability.

Table 3. Pearson's coefficient of correlation (r) of the residual from the set of data between seedling emergence and traditional accelerated aging (TAA), vigortetrazolium (VIG).

\begin{tabular}{cccc}
\hline \multirow{2}{*}{ Parameter } & \multirow{2}{*}{ Cultivar } & \multicolumn{2}{c}{ Tests } \\
\cline { 3 - 4 } & & TAA & VIG \\
\hline \multirow{3}{*}{ Seedling emergence } & BRS 184 & $0.839^{* *}$ & $0.909^{* *}$ \\
& M-Soy 7908 & $0.588^{* *}$ & $0.745^{* *}$ \\
& Both cultivars & $0.702^{* *}$ & $0.873^{* *}$ \\
\hline
\end{tabular}

${ }^{* *}$ correlation significant at $1 \%$.
Additionally, our data confirm the correlation between the seed vigor results as evaluated by the tetrazolium test and seedling emergence in sand substrate. Schuab et al. (2006) observed that vigor, as evaluated by the tetrazolium test, had a correlation of 0.66 with the emergence of in their studies on the physiological potential of seeds. In the present study, the observed values varied between 0.74 and 0.91 , with values significant at $1 \%$ probability (Table 3 ).

The other complementary tests (saturated accelerated aging with $\mathrm{NaCl}$ solution and SVIS) were applied to evaluate 
the seed quality of cultivar BRS 184 and with the exception of the uniformity and seedling length; these tests were also efficient for classifying seed vigor (Table 4). The saturated salt accelerated aging with $\mathrm{NaCl}$ for 72 and 96 hours and the vigor index (VI) were efficient for evaluating seed physiological potential once the lowest performance seed lot (lot 3) was identified. However, even though identifying seeds from lot 3 as having low performance, the saturated salt accelerated aging with $\mathrm{NaCl}$ for 48 hours was considered not efficient since it was unable to classify seeds from the lot 2 as having high performance. In environment $\mathrm{A}_{1}$ (Table 5), in general the results may classify seed lot 5 as the one with the highest physiological potential; the seed lots 3 and 1 were classified as low vigor. In environment $A_{2}$ (Table 5), which was less favorable for seed longevity, the rank based on physiological potential lot were varied. Nevertheless, seed lots 2 and 6 were highlighted as the best performers by accelerated aging with saturated $\mathrm{NaCl}$ solution for 72 hours, lot 6 by the accelerated aging with saturated $\mathrm{NaCl}$ for 96 hours, and lot 4 by the vigor index and the seedling length, both of which were obtained with the SVIS software. Seed lots 2, 4 and 6 had already been identified as the lots with the highest physiological potential by the tetrazolium test, which reveals the comparative efficiency of these tests (Table 1).

Table 4. Saturated salt accelerated aging with $\mathrm{NaCl}$ (SSAA), vigor index (VI), uniformity (U) and seedling length (SL) as determined by SVIS analysis of six lots of soybean seeds from cultivars BRS 184 and M-Soy 7908 RR before the beginning of storage.

\begin{tabular}{|c|c|c|c|c|c|c|c|}
\hline Cultivar & $\begin{array}{c}\text { Seed } \\
\text { Lot }\end{array}$ & SSAA (48 h) & $\begin{array}{l}\text { SSAA }(72 \mathrm{~h}) \\
\ldots \ldots \ldots . . .\end{array}$ & SSAA (96 h) & .... SVIS SVM $_{\text {T... }}$ & $\begin{array}{l}\mathrm{U} \\
\mathrm{M} \ldots .\end{array}$ & $\begin{array}{c}\mathrm{SL} \\
(\mathrm{cm})\end{array}$ \\
\hline \multirow{6}{*}{ BRS 184} & 1 & $94 \mathrm{a}^{*}$ & $94 \mathrm{a}^{*}$ & $91 \mathrm{a}^{*}$ & $766 a^{*}$ & $872^{\text {n.s. }}$ & $8.8^{\text {n.s. }}$ \\
\hline & 2 & $88 \mathrm{~b}$ & $88 \mathrm{a}$ & $92 \mathrm{a}$ & $786 \mathrm{a}$ & 859 & 9.0 \\
\hline & 3 & $79 \mathrm{c}$ & $82 \mathrm{~b}$ & $83 \mathrm{~b}$ & $686 \mathrm{~b}$ & 858 & 7.5 \\
\hline & 4 & $88 \mathrm{~b}$ & $93 \mathrm{a}$ & $86 \mathrm{~b}$ & $807 \mathrm{a}$ & 848 & 9.3 \\
\hline & 5 & $89 \mathrm{~b}$ & $92 \mathrm{a}$ & $89 \mathrm{a}$ & $804 \mathrm{a}$ & 874 & 9.5 \\
\hline & 6 & $92 \mathrm{a}$ & $93 \mathrm{a}$ & $90 \mathrm{a}$ & $738 \mathrm{~b}$ & 843 & 8.2 \\
\hline CV (\%) & & 3.5 & 4.5 & 4.8 & 8.1 & 4.5 & 10.4 \\
\hline \multirow{6}{*}{ M-Soy 7908 RR } & 7 & $97^{\text {n.s. }}$ & $95^{\text {n.s. }}$ & $94^{\text {n.s. }}$ & $874^{\text {n.s. }}$ & $883 b^{*}$ & $10.6 \mathrm{a}^{*}$ \\
\hline & 8 & 97 & 94 & 92 & 835 & $854 \mathrm{~b}$ & $8.4 \mathrm{~b}$ \\
\hline & 9 & 95 & 95 & 94 & 935 & $911 \mathrm{a}$ & $11.7 \mathrm{a}$ \\
\hline & 10 & 95 & 94 & 96 & 870 & $858 \mathrm{~b}$ & $10.6 \mathrm{a}$ \\
\hline & 11 & 95 & 93 & 90 & 857 & $870 \mathrm{~b}$ & $8.6 \mathrm{~b}$ \\
\hline & 12 & 97 & 96 & 94 & 920 & $902 \mathrm{a}$ & $9.6 \mathrm{~b}$ \\
\hline CV (\%) & & 2.9 & 2.4 & 2.4 & 5.9 & 2.9 & 8.6 \\
\hline
\end{tabular}

n.s. non-significant; ${ }^{*}$ significant at $5 \%$. Means followed by the same letter in the columns for each cultivar do not differ from each other according to the ScottKnott test at 5\% probability.

For cultivar M-Soy 7908 RR, only the uniformity and seedling length results evaluated by SVIS highlighted the physiological potential differences between soybean seeds (Table 4). However, the seeds from lot 7 were not classified as higher vigor following the results of the typically emphasized tests (Table 1). The seedling length results were similar to the ones from the accelerated aging test and the seedling emergence index, highlighting a lower physiological potential in seeds from lots 8,11 and 12. In both storage environments (Table 5), the results from the tests showing the use of saturated salt accelerated aging with $\mathrm{NaCl}$ for 72 hours indicated that the best seed performances were in lots 7 and 9 (Table 5). The vigor index obtained with SVIS was also efficient in identifying the lots with higher physiological potential. For $\mathrm{A}_{2}$ it was observed the saturated salt accelerated aging with $\mathrm{NaCl}$ for 96 hours indicated lots 7, 9 and 10 with high vigor seeds, as identified previously. Also, the saturated salt accelerated aging with $\mathrm{NaCl}$ for 72 hours and seedling length identified the seed lots with high performance.

For the complementary tests proposed in this study, the germination data obtained from saturated salt accelerated aging test with $\mathrm{NaCl}$ solution and parameters of vigor index and seedling length obtained by SVIS had high correlations with seedling emergence in sand substrate (Table 6). The saturated salt accelerated aging with $\mathrm{NaCl} 41{ }^{\circ} \mathrm{C}$ for 72 hours or saturated salt accelerated aging with $\mathrm{NaCl} 41{ }^{\circ} \mathrm{C}$ for 96 hours had 0.779 and 0.828 , respectively, when we used the two cultivars to analyze the data.

Within a period of 48 hours, the results with $\mathrm{NaCl}$ solution had high correlation but did not present similarities 
with the other vigor tests as we observed (Table 4), which made them difficult to use. Because the relative humidity was lower in saturated salt accelerated aging test with $\mathrm{NaCl}(76 \%$ $\mathrm{RH})$, longer time is necessary to promote seed deterioration than the traditional accelerated aging at the same temperature $\left(41^{\circ} \mathrm{C}\right)$. For this reason the saturated salt accelerated aging test with $\mathrm{NaCl}$ solution for 72 and 96 hours showed good correlations and similarities with the other tests.

Table 5. Saturated salt accelerated aging with $\mathrm{NaCl}$ (SSAA), vigor index (VI), uniformity (U) and seedling length (SL) determined in SVIS analysis from six lots of soybean seeds in cultivars BRS 184 and M-Soy 7908 RR, stored for four months in a controlled environment $\left(\mathrm{A}_{1}\right)$ and a uncontrolled environment $\left(\mathrm{A}_{2}\right)$.

\begin{tabular}{|c|c|c|c|c|c|c|c|c|}
\hline \multirow[t]{2}{*}{ Environment } & \multirow[t]{2}{*}{ Cultivar } & \multirow[t]{2}{*}{ Seed Lot } & $\begin{array}{l}\text { SSAA } \\
(48 \mathrm{~h})\end{array}$ & $\begin{array}{l}\text { SSAA } \\
(72 \mathrm{~h})\end{array}$ & $\begin{array}{l}\text { SSAA } \\
(96 \mathrm{~h})\end{array}$ & VI & $\mathrm{U}$ & \multirow{2}{*}{$\begin{array}{c}\mathrm{SL} \\
(\mathrm{cm})\end{array}$} \\
\hline & & & \multicolumn{3}{|c|}{. } & \multicolumn{2}{|c|}{$\ldots$. SVISTM $_{\ldots .}$} & \\
\hline \multirow{14}{*}{ BRS 184} & \multirow{6}{*}{$\mathrm{A}_{1}$} & 1 & $86 a^{*}$ & $81 \mathrm{a}^{*}$ & $66 \mathrm{a}^{*}$ & $603 c^{*}$ & $876^{\text {n.s. }}$ & $5.0 \mathrm{c}^{*}$ \\
\hline & & 2 & $90 \mathrm{a}$ & $84 \mathrm{a}$ & $71 \mathrm{a}$ & $696 \mathrm{~b}$ & 841 & $6.4 \mathrm{~b}$ \\
\hline & & 3 & $78 \mathrm{~b}$ & $72 \mathrm{~b}$ & $56 \mathrm{~b}$ & $582 \mathrm{c}$ & 810 & $4.9 \mathrm{c}$ \\
\hline & & 4 & $78 \mathrm{~b}$ & $76 \mathrm{~b}$ & $72 \mathrm{a}$ & $731 \mathrm{~b}$ & 813 & $7.1 \mathrm{a}$ \\
\hline & & 5 & $89 \mathrm{a}$ & $85 \mathrm{a}$ & $76 \mathrm{a}$ & $797 \mathrm{a}$ & 891 & $7.7 \mathrm{a}$ \\
\hline & & 6 & $87 \mathrm{a}$ & $81 \mathrm{a}$ & $74 \mathrm{a}$ & $705 \mathrm{~b}$ & 870 & $6.5 \mathrm{~b}$ \\
\hline & \multicolumn{2}{|c|}{$\mathrm{CV}(\%)$} & 5.1 & 5.7 & 6.3 & 6.7 & 3.6 & 9.9 \\
\hline & \multirow{6}{*}{$\mathrm{A}_{2}$} & 1 & $64 b^{*}$ & $47 c^{*}$ & $29 \mathrm{~d}^{*}$ & $388 \mathrm{~d}^{*}$ & $766^{\text {n.s. }}$ & $2.3 c^{*}$ \\
\hline & & 2 & $82 \mathrm{a}$ & $77 \mathrm{a}$ & $52 \mathrm{~b}$ & $583 \mathrm{c}$ & 812 & $5.0 \mathrm{~b}$ \\
\hline & & 3 & $64 \mathrm{~b}$ & $62 \mathrm{~b}$ & $39 \mathrm{c}$ & $455 \mathrm{~d}$ & 800 & $3.1 \mathrm{c}$ \\
\hline & & 4 & $75 \mathrm{a}$ & $67 \mathrm{~b}$ & $53 \mathrm{~b}$ & $752 \mathrm{a}$ & 824 & $7.3 \mathrm{a}$ \\
\hline & & 5 & $82 \mathrm{a}$ & $67 \mathrm{~b}$ & $48 \mathrm{~b}$ & $594 \mathrm{c}$ & 801 & $5.2 \mathrm{~b}$ \\
\hline & & 6 & $84 \mathrm{a}$ & $73 \mathrm{a}$ & $60 \mathrm{a}$ & $665 \mathrm{~b}$ & 854 & $5.9 \mathrm{~b}$ \\
\hline & \multicolumn{2}{|c|}{ CV (\%) } & 7.6 & 7.9 & 7.5 & 8.9 & 4.9 & 12.5 \\
\hline \multirow{14}{*}{ M-Soy 7908 RR } & \multirow{6}{*}{$\mathrm{A}_{1}$} & 7 & $91 \mathrm{a}^{*}$ & $90 a^{*}$ & $79 a^{*}$ & $815 \mathrm{a}^{*}$ & $881^{\text {n.s. }}$ & $7.9 \mathrm{a}^{*}$ \\
\hline & & 8 & $85 \mathrm{~b}$ & $81 \mathrm{~b}$ & $71 \mathrm{~b}$ & $719 b$ & 875 & $6.7 \mathrm{a}$ \\
\hline & & 9 & $93 \mathrm{a}$ & $93 \mathrm{a}$ & $81 \mathrm{a}$ & $829 a$ & 882 & $8.1 \mathrm{a}$ \\
\hline & & 10 & $89 a$ & $85 \mathrm{~b}$ & $81 \mathrm{a}$ & $745 \mathrm{~b}$ & 825 & $7.2 \mathrm{a}$ \\
\hline & & 11 & $82 \mathrm{~b}$ & $82 \mathrm{~b}$ & $69 \mathrm{~b}$ & $649 c$ & 865 & $5.6 \mathrm{~b}$ \\
\hline & & 12 & $83 \mathrm{~b}$ & $85 \mathrm{~b}$ & $79 \mathrm{a}$ & $731 \mathrm{~b}$ & 877 & $6.8 \mathrm{a}$ \\
\hline & \multicolumn{2}{|c|}{ CV (\%) } & 5.2 & 3.8 & 6.4 & 6.2 & 3.9 & 9.4 \\
\hline & \multirow{6}{*}{$\mathrm{A}_{2}$} & 7 & $91 \mathrm{a}^{*}$ & $91 \mathrm{a}^{*}$ & $80 a^{*}$ & $721 a^{*}$ & $870^{\text {n.s. }}$ & $6.6 a^{*}$ \\
\hline & & 8 & $74 \mathrm{~b}$ & $66 \mathrm{~d}$ & $43 c$ & $505 \mathrm{~b}$ & 831 & $3.7 \mathrm{c}$ \\
\hline & & 9 & $92 \mathrm{a}$ & $90 \mathrm{a}$ & $83 a$ & $731 \mathrm{a}$ & 838 & $7.1 \mathrm{a}$ \\
\hline & & 10 & $92 \mathrm{a}$ & $85 \mathrm{~b}$ & $76 \mathrm{a}$ & $691 \mathrm{a}$ & 843 & $6.6 \mathrm{a}$ \\
\hline & & 11 & $78 \mathrm{~b}$ & $69 \mathrm{~d}$ & $55 \mathrm{~b}$ & $537 \mathrm{~b}$ & 841 & $4.1 \mathrm{c}$ \\
\hline & & 12 & $86 \mathrm{a}$ & $78 \mathrm{c}$ & $60 \mathrm{~b}$ & $650 \mathrm{a}$ & 858 & $5.8 \mathrm{~b}$ \\
\hline & \multicolumn{2}{|c|}{$\mathrm{CV}(\%)$} & 5.2 & 4.1 & 5.4 & 6.7 & 4.5 & 9.3 \\
\hline
\end{tabular}

n.s. non-significant; * significant at 5\%. Means followed by the same letter in the column for each cultivar do not differ from each other according to the ScottKnott test at $5 \%$ probability.

Table 6. Pearson's Coefficient of Correlation (r) of the residual from the set of data between seedling emergence (E) and tradicional accelerated aging (TAA), vigor-tetrazolium (VIG), accelerated aging with satured $\mathrm{NaCl}$ solution (SSAA), vigor index (VI), uniformity (U) and seedling length (SL) as determined by SVIS analysis.

\begin{tabular}{|c|c|c|c|c|c|c|c|c|c|}
\hline \multirow{2}{*}{ Test } & \multirow{2}{*}{ Cultivar } & \multicolumn{8}{|c|}{ Tests } \\
\hline & & TAA & VIG & SSAA (48 h) & SSAA $(72 \mathrm{~h})$ & SSAA (96 h) & VI & $\mathrm{U}$ & SL \\
\hline \multirow{3}{*}{$\mathrm{E}$} & BRS 184 & $0.839 * *$ & $0.909 * *$ & $0.830 * *$ & $0.875 * *$ & $0.871 * *$ & $0.854 * *$ & $0.796 * *$ & $0.873 * *$ \\
\hline & M-Soy 7908 RR & $0.588 * *$ & $0.745 * *$ & $0.670 * *$ & $0.670 * *$ & $0.688 * *$ & $0.594 * *$ & $0.488 * *$ & $0.603 * *$ \\
\hline & Both cultivars & $0.702 * *$ & $0.873 * *$ & $0.779 * *$ & $0.779 * *$ & $0.828 * *$ & $0.765 * *$ & $0.735 * *$ & $0.762 * *$ \\
\hline
\end{tabular}

${ }^{* *}$ correlation significant at $1 \%$. 
The advantage to use the computerized image analysis was to classify the seed lots within only three days, instead of to six days necessary for the traditional accelerated aging test (two days for deterioration treatment + four days for germination test) and to seven and eight days for the saturated salt accelerated aging test with $\mathrm{NaCl}$ for 72 and 96 hours.

Since its introduction for seed quality evaluations, seedling image analysis has shown its effectiveness for classifying seed lots from several plants, including maize (Hoffmaster et al., 2005), soybean (Marcos-Filho et al., 2009) and sweet corn (Alvarenga et al., 2012). Nevertheless, according to GomesJunior et al. (2009), the procedure for evaluating seed vigor with SVIS is simple, and the results for this sample may be obtained within two to three minutes. Other advantages of this analysis system include the overcoming of human error, which increases the reliability of data for comparison among different laboratories, the possibility of storing images for further analysis and the low cost of management.

The results from the six-month storage period (data not shown) restated the results from the previous two months. Importantly, the seed lots generally had a physiological potential lower than that previously determined for both cultivars under both environment conditions $\left(\mathrm{A}_{1}\right.$ and $\left.\mathrm{A}_{2}\right)$.

\section{Conclusions}

The tetrazolium test is the most advisable method for evaluating soybean seed quality during storage. The results of the saturated salt accelerated aging test with $\mathrm{NaCl}$ at $41^{\circ} \mathrm{C}$ for 72 or 96 hours and the SVIS evaluation are also both efficient for estimating the physiological potential of seeds. The use of SVIS decreased the evaluation period for seed quality compared to the time required for the accelerated aging test with water or saturated $\mathrm{NaCl}$ solution.

\section{Acknowledgements}

The authors acknowledge the "Fundação de Amparo à Pesquisa do Estado de São Paulo" (FAPESP) and the "Conselho Nacional de Desenvolvimento Científico e Tecnológico" (CNPq), for the financial support to this research, and to Embrapa Soybean for providing the seed lots. The authors are grateful to professor Julio Marcos-Filho for his technical guidance.

\section{References}

ALVARENGA, R.O.; MARCOS-FILHO, J.; GOMES-JUNIOR, F.G. Avaliação do vigor de sementes de milho superdoce por meio da análise computadorizada de imagens de plântulas. Revista Brasileira de Sementes, v.34, n.3, p.488-494, 2012. http://dx.doi.org/10.1590/S010131222012000300017

BAALBAKI, R.; ELIAS, S.; MARCOS-FILHO, J.; McDONALD, M.B. Seed vigor testing handbook, Contribution n.32 to the Handbook on Seed Testing. Ithaca: Association of Official Seed Analysts, 2009. 346 p.

BARBOSA, R.M.; COSTA, D.S.; SÁ, M.E. Envelhecimento acelerado em sementes de alface. Ciência Rural, v.41, n.11, p.1899-1902, 2012. http:// dx.doi.org/10.1590/S0103-84782011005000138

BRASIL. Ministério da Agricultura, Pecuária e Abastecimento. Regras para análise de sementes. Ministério da Agricultura, Pecuária e Abastecimento. Secretaria de Defesa Agropecuária. Brasília: MAPA/ACS, 2009. 395p. http:// www.agricultura.gov.br/arq_editor/file/2946_regras_analise_sementes.pdf

COSTA, N.P.; MESQUITA, C.M.; MAURINA, A.C.; FRANÇA-NETO, J.B.; KRZYZANOWSKI, F.C.; HENNING, A.A. Qualidade fisiológica, física e sanitária de sementes de soja produzidas no Brasil. Revista Brasileira de Sementes, v.25, n.1, p.128-132, 2003. http://dx.doi.org/10.1590/S010131222003000100020

COSTA, N.P.; MESQUITA, C.M.; MAURINA, A.C.; FRANÇA-NETO, J.B.; KRZYZANOWSKI, F.C.; OLIVEIRA, M.C.N; HENNING, A.A. Perfil dos aspectos físicos, fisiológicos e químicos de sementes de soja produzidas em seis regiões do Brasil. Revista Brasileira de Sementes, v.27, n.2, p. 1-6, 2005. http://dx.doi.org/10.1590/S0101-31222005000200025

FEHR, W.R.; CAVINESS, C.E. Stages of soybean development. Ames: Iowa State University of Science and Technology, 1977. 11p.

FESSEL, S.A.; SILVA, L.J.R.; GALLI, J.A.; SADER, R. Uso de solução salina $(\mathrm{NaCl})$ no teste de envelhecimento acelerado em sementes de brócolis (Brassica oleracea L. var. italica Plenk). Cientifica, v.33, n.1, p.27-34, 2005. http://www.cientifica.org.br/index.php/cientifica/article /view/130

FRANÇA-NETO, J.B.; KRZYZANOWSKI, F.C.; COSTA, N.P. The tetrazolium test for soybean seeds. Londrina-PR: EMBRAPA-CNPSo, 1998, 71p. (Documentos, 115).

FRANÇA-NETO, J.B.; KRZYZANOWSKI, F.C.; COSTA, N.P.; HENNING, A.A.; PÁDUA, G.P. Adequação de metodologia de testes de vigor para sementes de soja. Resultados de Pesquisa da Embrapa Soja - 2002: sementes e transferência de tecnologia. p.25-32, 2003. (Documentos, 211).

GOMES-JUNIOR, F.G.; MONDO, V.H.V.; CICERO, S.M.; McDONALD, M.B.; BENNETT, M.A. Evaluation of priming effects on sweet corn seeds by SVIS. Seed Technology, v.31, n.1, p.95-100, 2009.

HOFFMASTER, A.L.; FUJIMURA, K.; McDONALD, M.B.; BENNETT, M.A. An automated system for vigor testing three-day-old soybean seedlings. Seed Science and Technology, v.31, n.3 p.701-713, 2003. http://www. ingentaconnect.com/content/ista/sst/2003/00000031/00000003/art 00019

HOFFMASTER, A.F.; XU, L.; FUJIMURA, K.; McDONALD, M.B.; BENNETT, M.A.; EVANS, A.F. The Ohio State University seed vigor imaging system (SVIS) for soybean and corn seedlings. Seed Technology, v.27, n.1, p.7-24, 2005.

INTERNATIONAL SEED TESTING ASSOCIATION. International Rules for Seed Testing Association. Zürich: ISTA, 2004. 174p. 
JIANHUA, Z.; MCDONALD, M.B. The salt accelerated aging test for smallseeded crops. Seed Science and Technology, v.25, n.1., p. 123-131, 1996.

MAGUIRE, J.D. Speed of germination-aid in relation evaluation for seedling emergence vigor. Crop Science, v.2, n.1, p.176-177, 1962.

MARCOS-FILHO, J.; KIKUTI, A.L.; LIMA, L.B. Métodos para avaliação do vigor de sementes de soja, incluindo a análise computadorizada de imagens. Revista Brasileira de Sementes, v.31, n.1, p.102-112, 2009. http:// dx.doi.org/10.1590/S0101-31222009000100012

MATTHEWS, S.; NOLI, E.; DEMIR, I.; KHAJEH-HOSSEINI, M.; WAGNER, M.H. Evaluation of seed quality: from physiology to international standardization. Seed Science Research, v.22, Supplement S1, p.S69-S73, 2012. http://dx.doi.org/10.1017/S0960258511000365

MENDONÇA, E.A.F.; AZEVEDO, S.C.; GUIMARÃES, S.C.; ALBUQUERQUE, M.C.F. Testes de vigor em sementes de algodoeiro herbáceo. Revista Brasileira de Sementes, v.30, n.3, p.01-09, 2008. http:// dx.doi.org/10.1590/S0101-31222008000300001

MOREANO, T.B.; BRACCINI, A.L.; SCAPIM, C.A.; KRZYZANOWSKI, F.C.; FRANÇA-NETO, J.B.; MARQUES, O.J. Changes in the effects of weathering and mechanical damage on soybean seed during storage. Seed Science and Technology, v.39, n.3, 604-611, 2011. http://www.ingentaconnect. com/content/ista/sst/2011/00000039/00000003/art00007

RAMOS, N.P.; FLOR, E.P.O.; MENDONÇA, E.A.F.; MINAMI, K. Envelhecimento acelerado em sementes de rúcula (Eruca sativa L.). Revista Brasileira de Sementes, v.26, n.1, p.98-103, 2004. http://dx.doi.org/10.1590/ S0101-31222004000100015

SANTOS, P.M.; GONDIM, T.C.O.; ARAÚJO, E.F.A.; DIAS, D.C.F.S. Avaliação da qualidade fisiológica de sementes de milho-doce pelo teste de envelhecimento acelerado. Revista Brasileira de Sementes, v.24, n.1, p.9196, 2002. http://dx.doi.org/10.1590/S0101-31222002000100013
SCHUAB, S.R.P.; BRACCINI, A.L.; FRANÇA-NETO, J.B.; SCAPIM, C.A.; MESCHEDE, D.K. Potencial fisiológico de sementes de soja e sua relação com a emergência das plântulas em campo. Acta Scientiarum Agronomy, v.28, n.4, p.553-561, 2006. http://dx.doi.org/10.4025/actasciagron. v28i4.928

SILVA, M.A.D.; VIEIRA, R.D.; SANTOS, J.M. Influência do envelhecimento acelerado na anatomia da testa de sementes de soja, cv. Monsoy 8400. Revista Brasileira de Sementes, v.30, n.2 p. 91-99, 2008. http://dx.doi.org/10.1590/ S0101-31222008000200012

TIAN, X.; SONG, S.; LEI, Y. Cell death and reactive oxygen species metabolism during accelerated ageing of soybean axes. Russian Journal of Plant Physiology, v.55, n.1, p.33-40, 2008. http://dx.doi.org/10.1134/ S1021443708010032

TORRES, S.B. Envelhecimento acelerado em sementes de pepino com e sem solução salina saturada. Horticultura Brasileira, v.23, n.2, p.303-306, 2005. http://dx.doi.org/10.1590/S0102-05362005000200028

TORRES, R.M.; VIEIRA, R.D.; PANOBIANCO, M. Accelerated aging and seedling field emergence in soybean. Scientia Agricola, v.61, n.5, p.476-480, 2004. http://dx.doi.org/10.1590/S0103-90162004000500002

WRASSE, C.F.; MENEZES, N.L.; MARCHESAN, E.; VILLELA, F.A.; BORTOLOTTO, R.P. Testes de vigor para sementes de arroz e sua relação com o comportamento de hidratação de sementes e a emergência de plântulas. Cientifica, v.37, n.2, p.107-114, 2009. http://www.cientifica.org.br/index. $\mathrm{php} / \mathrm{cientifica/article/view/287}$ 